\title{
THE TREATMENT OF SYPHILIS WITH PENICILLIN
}

\author{
BY \\ E. M. LOURIE
}

In Liverpool we were early in the field in suggesting that penicillin might be used for the treatment of syphilis. Actually, our initial observation that penicillin is effective against the spirochætes of relapsing fever and of rat-bite fever was made in August, 1942. Although we made no secret of this information, it did not appear in print until the publication of the Annual Report of the Liverpool School of Tropical Medicine for the year ending July, 1943, and then of the Annals of Tropical Medicine and Parasitology for December, 1943. In our paper in the Annals we pointed out that since both Spirochata recurrentis and Spirillum minus infections are, on the whole, eminently amenable' to treatment by standard anti-syphifftic arsenicals, and since we had found these infections susceptible also to penicillin, the question naturally arose whether penicillin would not be effective also against syphilis (Lourie and Collier, 1943). The suggestion was published, therefore, almost simultaneously with the famous announcement by Mahoney and others, also in December, 1943, that they had, in fact, found penicillin to be effective against syphilis. For some time before this announcement we had ourselves tried unsuccessfully to obtain, from the carefully conserved stocks of penicillin in this country, an allocation for the trials against syphilis to which our animal work had logically pointed. However, the invasion of Europe was imminent, and it seemed that every unit of penicillin in this country had to be held in readiness for battle casualties on an unpredictable and possibly unprecedented scale. The United States had by then already far outstripped Great Britain in the production and general availability of penicillin.

\section{The Trials at Liverpool}

In conjunction with my colleague, Dr. A. O. Fergusson Ross, without whose willing and generous co-operation nothing could have been achieved on the clinical side, the detailed procedure for our projected trials against syphilis had already been fully decided by the time that Mahoney and his. co-workers had made their announcement. It was by the merest coincidence that, without knowing anything of the activities of Mahoney's group in this connexion, we chose a total dosage per case of 2.4 million units, which was exactly twice that which they chose. We decided on 2.4 million units because it seemed, from a survey of published clinical work on penicillin at that time, to be about the highest amount we could reasonably plan to use, at any rate for the first few cases. The total happened to be 2.4 million rather than the more rounded figure of 2.5 million, merely because we expected our supplies to be in bottles each containing 60,000 units, and we therefore decided that a convenient and suitable individual dose should be 30,000 units, which we proposed to repeat every three hours for ten days, thereby aggregating 2.4 million units for the entire course.

It is amusing, in retrospect now, to recall that we were, in some quarters, criticized for being prepared to use such "excessive" dosages for this early work. However, the idea was that there would be an ultimate economy both in time and materials, quite apart from the point of view of the patients' best interests; if we chose to begin with what then seemed an intensive and maximal form of treatment. If penicillin should eventually prove to be of little use against syphilis, then the more intensive our initial trial-courses of treatment the more quickly and economically would that eventual conclusion be reached. If, on the other hand, penicillin should eventually prove to. be a really useful weapon against syphilis, then, by using an intensive form of treatment for our initial trials, we would be able, in subsequent tests, gradually to scale down the dosage, if thought desirable for the sake of economy or for any other reason, until the minimum effective level was reached and defined.

We did eventually, though rather belatedly, obtain an allocation of penicillin for investigation 
against human syphilis, through the Penicillin Clinical Trials Committee of the Medical Research Council, and we carried out our plan of treatment by 2.4 million units in four cases of secondary syphilis (Ross and others, 1944). Although the immediate response was excellent in each of these patients, only one of them could be rated an unequivocal success over an observation-period of nine months. We therefore expressed ourselves as doubtful whether the penicillin had been as beneficial as arsenicals and bismuth might have been.

\section{American-Trials}

The large-scale trials which were at the same time under way in the United States involved about 1,500 cases of early syphilis (apart from nearly 200 late cases), divided into groups treated respectively with total dosages of $60,000,300,000,600,000$, and $1,200,000$ units, and in due course a conclusion essentially similar to our own was reached, namely that "certainly the minimum dose, especially in secondary syphilis, should not be less than $1,200,000$ units ; probably it should be more" (Moore and others, 1944). Our own series of four patients threw doubt even on $2,400,000$ units.

\section{Caution and Enthusiasm}

These early cautionary notes were hardly echoed in the numerous enthusiastic reports which rapidly multiplied in the early days, but there has since been a general swing-back to caution and doubt, as for example in Marshall's paper before the Royal Society of Medicine last year, and there are probably few clinicians in this country now who would not prefer to play safe by administering arsenicals together with penicillin in early syphilis. It is true that a good deal of this shadow, which during the past year or two has slowly passed over penicillin as a remedy for syphilis, has now been attributed to the fact that since 1944 an increasingly large proportion of penicillin IV, and correspondingly less penicillin II, has come to be contained in commercial preparations. However, our early cautionary note was struck with the first cases treated, when, as we have every reason to believe, the penicillin of commercially produced preparations was predominantly penicillin II.

\section{Size of Dose}

Nevertheless, the earliest reports did clearly establish that penicillin is highly efficacious against syphilis, and it seems to me that there has always been a singular reluctance to find out whether this degree of efficacy could not be stepped up by a bold increase in dosage. I feel that if penicillin had been found to be poisonous in excessive doses, and if it had then been established that the upper level of safety, in a single dose, were, say, 500,000 units, then 500,000 units would now be the customary dose per injection in general practice. But it has been found to be a non-toxic substance, and yet it took a very long time before anyone dared to emancipate himself from dosages of 30 or 40,000 units per injection. It is true that costs must always be taken into consideration, but investigations of intensive treatments on relatively small numbers of cases might in the end have been an economy, since the price of penicillin was bound to fall, and the eventual cost, to the individual and to the community, of inadequately treated syphilis will surely be greater than the cost of initial treatments with generous dosages of penicillin.

The results of laboratory work were, of course, invoked to show the futility of massive doses. It was claimed for example that the wastage through excretion, etc., is proportionately so greatly increased with increasing dosage, that little advantage might be expected to result from the use of massive-dose treatment-schedules. Also it has been claimed that penicillin blood-levels above a certain threshold are no more spirochæticidal than at that level (Eagle and Musselman, 1944). I would be the very last to decry the value of laboratory research as a pointer towards optimum clinical practice, but nevertheless the test-tube, much as I am myself addicted to it, does not give us the final answer ; and, in any case, some of the laboratory-based arguments against massive dosage have already been challenged or countered by further laboratory work, which there is, unfortunately, no space to describe (Lourie and others, 1945 ; Florey and others, 1946). This laboratory work encouraged us to find out what penicillin can do against early syphilis when it is given in massive doses. In planning these further clinical trials, however, we constantly kept in mind the necessity of arriving at a form of treatment which does not require hospitalization, and which, indeed, calls for the barest minimum of time spent in the clinic, so that the patients' daily work or routine need hardly be disturbed. It was a pleasure to find that Surgeon-Captain Lloyd Jones, R.N., was independently, and with considerable success, working along somewhat similar lines (Lloyd Jones and Maitland, 1945).

\section{The Present Investigation}

In this particular investigation, a preliminary account of which has already appeared (Lourie and others, 1945) we have confined ourselves to the use of watery solutions of penicillin, rather than penicillin in some medium such as peanut oil and beeswax, designed to delay absorption. This we 
TABLE I

EARLY SYPHILIS TREATED WITH MASSIVE-DOSE PENICILLIN

\begin{tabular}{|c|c|c|c|c|c|c|c|c|c|}
\hline \multirow{4}{*}{$\begin{array}{l}\text { Type of } \\
\text { infection }\end{array}$} & \multirow{4}{*}{$\begin{array}{l}\text { Treatment } \\
\text { course* }\end{array}$} & \multicolumn{2}{|c|}{ Followed for 20 weeks } & \multicolumn{6}{|c|}{ Followed for $12-18$ months } \\
\hline & & \multirow{3}{*}{ Cases } & \multirow{3}{*}{$\begin{array}{c}\text { W.R. negative within } \\
8 \text { weeks } \dagger \text { or } 8-16 \\
\text { weeks } \ddagger\end{array}$} & \multirow{3}{*}{ Cases } & \multirow{3}{*}{$\begin{array}{l}\text { W.R. still } \\
\text { negative }\end{array}$} & \multicolumn{4}{|c|}{ Failures } \\
\hline & & & & & & \multirow[b]{2}{*}{$\begin{array}{c}\text { W.R. } \\
\text { never } \\
\text { negative }\end{array}$} & \multicolumn{2}{|c|}{ Relapsed } & \multirow{2}{*}{$\begin{array}{c}\text { Probable } \\
\text { reinfec- } \\
\text { tions }\end{array}$} \\
\hline & & & & & & & $\begin{array}{l}\text { Serol. } \\
\text { only }\end{array}$ & $\begin{array}{l}\text { Clin. or } \\
\text { clin. and } \\
\text { serol. }\end{array}$ & \\
\hline \multirow[t]{2}{*}{$\begin{array}{l}\text { Sero- } \\
\text { positive } \\
\text { primary }\end{array}$} & $\begin{array}{l}1 \\
2 \\
3\end{array}$ & $\begin{array}{r}17 \\
16 \\
2\end{array}$ & $\begin{array}{r}14 \\
13 \\
1\end{array}$ & $\begin{array}{r}11 \\
13 \\
2\end{array}$ & $\begin{array}{r}9 \\
12 \\
1\end{array}$ & $\begin{array}{l}2 \S \\
\cdots \\
.\end{array}$ & $\begin{array}{l}\cdots \\
\cdots \\
\cdots\end{array}$ & $\ddot{1}$ & $\begin{array}{l}\cdots \\
\cdots \\
.\end{array}$ \\
\hline & & & $\begin{array}{l}\text { W.R. negative } \\
\text { within } 20 \text { weeks }\end{array}$ & & & & & & \\
\hline Secondary & $\begin{array}{l}1 \\
2 \\
3\end{array}$ & $\begin{array}{r}41 \\
24 \\
3\end{array}$ & $\begin{array}{r}33 \\
20 \\
1\end{array}$ & $\begin{array}{r}29 \\
21 \\
3\end{array}$ & $\begin{array}{r}21 \\
17 \\
2\end{array}$ & $\begin{array}{l}2 \S \\
1 \\
1 \S\end{array}$ & $\begin{array}{l}1 \\
\cdots \\
\cdots\end{array}$ & $\begin{array}{l}1 \\
\cdots \\
\cdots\end{array}$ & $\begin{array}{l}4 \\
3 \\
.\end{array}$ \\
\hline
\end{tabular}

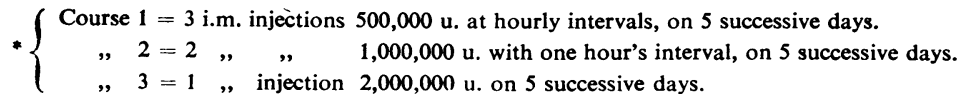

$\dagger$ Where initial titre was less than 100 .

$\ddagger$ Where initial titre was more than 100 .

$\$$ Includes one patient who reappeared with a positive Wassermann reaction after an absence of about a year, and who really may, therefore, be a case of serological relapse.

have done not merely because of the technical advantages and convenience of using aqueous solutions, but because, as my earlier remarks suggest, an overall appraisal of the laboratory evidence has not entirely convinced us that an incontestable case has been made out for the great superiority of relatively low and sustained blood-levels, as compared with intermittent high peaks of penicillincontent.

Three different treatment-courses have now been investigated, in a relatively small number of patients. Course 1 consisted of three intramuscular injections of 500,000 units at hourly intervals, repeated on five successive days, that is, to a total of $7.5 \mathrm{mega}$ units per case ; course 2 consisted of two intramuscular injections of $1,000,000$ units, with an hour's interval between each injection, repeated on five successive days, that is, to a total of 10 mega units per case ; and course 3 comprised a single intramuscular injection of $2,000,000$ units on five successive days, that is, also to a total of 10 mega units per case.* In most of the treatments the penicillin was present, to the amount of at least 80 per cent., in the form of penicillin II, but it is not possible to

\footnotetext{
* A few of the patients recorded as having been treated with courses comprising injections of $500,000,1,000,000$, and $2,000,000$ units respectively, were in fact treated with courses of $600,000,900,000$, and $1,800,000$ units respectively.
}

be quite sure of this in the earliest samples used. A number of cases have also been treated with crystalline preparations containing about 95 per cent. penicillin II. We have, so far, had no cause to believe that partly purified preparations may be more efficacious than highly purified, or crystalline, specimens of penicillin II, as was suggested by the laboratory work of Dunham and Rake (1945). Our own investigations on Spirochata recurrentis infections in mice likewise have pointed to no superiority of partly purified penicillin II, as compared with crystalline preparations (Williamson and Lourie, 1946).

In Table I the results have been summarized. The criterion adopted as a short-term measure of success is that in sero-positive primary syphilis the Wassermann reaction should be reversed within eight weeks where the initial titre was less than 100 , or within sixteen weeks where the titre was more than 100 ; in secondary syphilis the reaction should be reversed within 20 weeks. $\dagger$

Course 3 need not be pursued further ; it satisfied the short-term requirement in only two cases out of five. Courses 1 and 2 have each resulted in a high proportion of successes, and they seem to have

† We are obliged to Professor D. T. Robinson for performing the quantitative blood Wassermann reactions. 
been about equally efficacious. Combining the results of these two courses we have 27 successes out of 33 (or 82 per cent.) in sero-primary syphilis, and 53 out of 65 (again 82 per cent.) in secondary syphilis (see Table II). I should point out that probable reinfections are included among the failures. Reinfections occurring shortly after the beginning of treatment, which, of course, are frequently not identifiable with certainty as reinfections, are much more likely to prejudice the results obtained after an intensive treatment of short duration than those obtained after an orthodox course of injections extending over many months. During the latter form of treatment each injection is potentially able to wipe the slate clean again, in the event of a reinfection having occurred since the start of treatment. But after an intensive course of short duration, a reinfection is free to continue unchecked, and to simulate failure of treatment.

\section{TABLE II}

COMBINED RESULTS OF COURSES 1 AND 2 (SEE TABLE I). DENOMINATOR SHOWS CASES TREATED, NUMERATOR CASES RESPONDING FAVOURABLY

\begin{tabular}{c|cc|cc}
\hline $\begin{array}{c}\text { Type of } \\
\text { infection }\end{array}$ & $\begin{array}{c}\text { W.R. negative } \\
\text { within 8, 16, } \\
\text { or 20 weeks }\end{array}$ & $\begin{array}{c}\text { W.R. still } \\
\text { negative after } \\
12-18 \\
\text { months }\end{array}$ \\
\hline $\begin{array}{c}\text { Sero-positive } \\
\text { primary }\end{array}$ & $\frac{27}{33}$ & $(82 \%)$ & $\frac{21}{24}$ & $(87 \cdot 5 \%)$ \\
\hline Secondary & $\frac{53}{65}$ & $(82 \%)$ & $\frac{38}{50}$ & $(76 \%)$ \\
\hline
\end{tabular}

Turning now to the results of cases followed up for twelve to eighteen months, there is again nothing to choose between course 1 and course 2. Again combining the results of these two courses, we find that among primary cases 21 out of $24(87.5$ per cent.), and among secondary cases 38 out of 50 (76 per cent.), are still sero-negative twelve to eighteen months after treatment. If we put the most optimistic interpretation on our results, by classing as sero-negative the 7 cases which were probably reinfected after treatment, and also the 2 cases in which it is impossible to form any opinion as to whether a relapse or a reinfection had occurred, we would have 22 successes out of 24 (92 per cent.) in patients treated in the sero-positive stage, and 46 out of 50 (also 92 per cent.) in patients treated in the secondary stage.

The success-rate over this admittedly very short observation-period of twelve to eighteen months may then be stated as 87 to 92 per cent. for primary syphilis, and 76 to 92 per cent. for secondary syphilis. This is, of course, far from ideal, and may not be as good as may be obtained by other forms of treatment. It does, however, represent a high standard of efficacy, and it possesses the great virtue of being produced by a five-day course of ambulatory treatment which has involved the patient in no more than one or two hours' attendance at the clinic on each of the five days. If we were to combine this form of treatment with daily injections of, say, $0.09 \mathrm{~g}$. neohalarsine, or $0.06 \mathrm{~g}$. mapharside, administered at some time during the hour which separates the two massive penicillin injections of, say, course 2 , it is likely that we would be producing results against early syphilis as good as any now obtained by any other form of treatment, but involving smaller demands on the patients' time and convenience than any treatment-course now in general use.

Before concluding, I would like to pay tribute to the Americans for their efforts in reaching out towards the best means of treating syphilis. Dr. Moore has been in the vanguard of this campaign. His authority and influence have had no mere parochial limitations, but, through his writings and his Chairmanship of National Research Council and National Institute of Health committees, they have extended in a very direct manner over the whole of the United States, and indirectly, one might truly say, over the rest of the world as well. The organization, boldness, scope, discipline, and achievement of the American campaign against syphilis, of recent years, so largely guided and inspired by Dr. Moore, must make us ask ourselves whether anything of that kind will ever be possible over here.

\section{Summary and Conclusions}

Insufficient attention has hitherto been directed to the potentialities of massive-dose penicillin therapy for early syphilis. Some results of such treatment are here described. The courses were designed to take into account the necessity that treatment should be ambulatory, involving a minimal number of attendances at the clinic, of not more than one or two hours per visit, so that there need be no serious interference with the patients' normal daily routine.

The courses investigated were :

1. Three intramuscular injections of 500,000 units at hourly intervals, on five successive days (total 7.5 mega units).

2. Two intramuscular injections of $1,000,000$ units with an hour's interval between each injection, on five successive days (total 10 mega units): 
3. A single intramuscular injection of $2,000,000$ units on five successive days (total 10 mega units).

Only 5 cases were treated by course 3 , as the preliminary results in these patients were not very promising.

Courses 1 and 2 have given satisfactory results, and seemed to be equally efficacious. Combining the figures for these two courses, over an observation period of twelve to eighteen months, 87 to 92 per cent. of 24 primary cases, and 76 to 92 per cent. of 50 secondary cases are provisionally regarded as having been successfully treated.

It is suggested that a combination of massive dose penicillin therapy with treatment by arsenicals, say by daily injections of $0.09 \mathrm{~g}$. neohalarsine or $0.06 \mathrm{~g}$. mapharside administered during the hour which separates the two penicillin injections of course 2, may produce results as good as are now obtained by any other form of treatment, and involving considerably fewer demands on the patients' time and convenience.

\section{- References}

Dunham, W. B., and Rake, G. (1945). Amer. J. Syph. 29, 214.

Eagle, H., and Musselman, A. D. (1944). J. exp. Med., 80, 493 .

Florey, M. E., Turton, E. C., and Duthie, E. S. (1946). Lancet, 2, 405.

Liverpool School of Tropical Medicine, 44th Annual Report, August 1, 1942-July 31, 1943, p. 9.

Lloyd Jones, T. R., and Maitland, F. G. (1945). Brit. J. vener. Dis., 21, 65 .

Lourie, E. M., and Collier, H. O. J. (1943). Ann. trop. Med. Parasitol., 37, 200.

Collier, H. O. J., Ross, A. O. F., Nelson, R. B., Robinson, D. T. (1945). Lancet, $2,696$.

Mahoney, J. F., Arnold, R. C., and Harris, A. (1943). J. vener. Dis. Inform., 24, 355.

Marshall, J. (1946). Proc. roy. Soc. Med., 39, 465.

Moore, J. E., Mahoney, J. F., Schwartz., W. H., Sternberg, T. H., and Wood, W. B. (1944).' J. Amer. med. Ass., 126, 67.

Ross, A. O. F., Nelson, R. B., Lourie, E. M., Collier, H. O. J. (1944). Lancet, 2, 845.

Williamson, J., and Lourie, E. M. (1946). Brit. med.J., $1,828$. 